\title{
INCOME INEQUALITY IN ADVANCED CAPITALISM: \\ How Protective InSTITUTIONS CAN Promote EgalitaRian SociETIES
}

\author{
Christopher Kollmeyer \\ Department of Sociology \\ University of Aberdeen
}

\begin{abstract}
This study develops a Polanyian perspective on income inequality in advanced capitalist countries. Polanyi's historical account of the rise and fall of classic liberalism in Britain illustrated how social groups and society at large devised "protective institutions" to shield themselves from socially destructive market forces. Recent qualitative applications of this idea identify three protective institutions as being the most important-the public sector economy, trade unions, and the family. Using data from 16 Western countries from 1970 to 2010, this study demonstrates that cross-national and temporal variations in these protective institutions explain a considerable amount of the observed patterns of income inequality among these countries, helping to explain why some countries have recently experienced rising inequality but others have not. The study ends by arguing that a Polanyian perspective provides more analytical and theoretical leverage than other sociological approaches to understanding income inequality.
\end{abstract}

Keywords: Income Inequality; Karl Polanyi; Economic Sociology; Protective Institutions; the Great U-Turn

Post peer-reviewed, pre-published draft of "Income Inequality in Advanced Capitalism: How Protective Institutions can Promote Egalitarian Societies." Comparative Sociology, 2014 13(4): 419-444. 


\section{INCOME INEQUALITY IN ADVANCED CAPITALISM: How Protective InSTITUTIONS CAN Promote EgalitaRian SociETIES}

\section{INTRODUCTION}

Income inequality has risen in many but not all affluent countries over recent decades. A widely embraced explanation for this phenomenon comes from studies of labor markets in the United States (Acemoglu 1998; Autor, Katz, and Kearney 2008; Levy and Murnane 2003). Broadly speaking, these studies hold that "skilled-biased technological change"-brought about by the information revolution, globalization, and deindustrialization-has heightened demand for high-skilled workers, but diminished demand for less-skilled workers, thereby widening the wage-gap between workers with different skill levels. Hence, it is thought that changing market forces underlie most of the rising income inequality in the United States, and by extension other similar countries. However, this explanation faces a serious empirical anomaly when applied to other Western countries. Simply stated, the empirical anomaly is that the some of the world's most technologically advanced, globally integrated, and deindustrialized countries—such as the Nordic countries-are also some of the world's most egalitarian.

Given that economic explanations alone cannot account for the observed crossnational and temporal variations in income inequality, sociologists and related social scientists often emphasize factors lying beyond the strict sphere of the market. One such perspective views class-based political struggles, and their effects on social welfare policies and labor market institutions, as key determinants of income inequality (Bradley et al 2003; Brady and Leicht 2008; Mahler 2004). Another perspective emphasizes changes in the size of economically vulnerable populations, such as single mothers and the elderly, and how these demographic trends may affect the distribution of income (Esping-Andersen 2007; Kollmeyer 2013; McLanahan and Percheski 2008; Western, Bloome and Percheski 2008). Overall, the focus on non-market institutions is especially promising, largely because such institutions vary considerably across countries otherwise experiencing similar levels of "skilled-biased technological change."

The present study seeks to combine these sociological approaches into an overarching Polanyian account of how non-market institutions affect the national distribution of income in advanced capitalist countries. In his well-known analysis of the 
rise and fall of classic liberalism, Polanyi (1944) detailed how the drive to expand the scope of markets in Britain destabilized and nearly overwhelmed the larger society in which these markets were embedded. A particularly interesting sociological aspect of his analysis centers on the ways in which broadly defined social groups sought to shield themselves from destructive market forces by building "protective institutions." In this way, Polanyi saw the mobilization for social protection as central to the process of capitalist development. This idea has recently been extended by Ringmar (2005), who identifies the state, guilds and trade unions, and the family as being historically the most important protective institutions in Western and East Asian societies. These protective institutions, he argues, are important because they help to reconcile capitalism's need for dynamism and private gain with society's need for stability and social justice (see also Breen 1997).

In what follows, this study draws on Polanyi to argue that changes in three "protective institutions" largely account for the unique patterns of income inequality found across Western countries over recent decades. Although Polanyi's ideas have been used to study the dynamics of social stratification in socialist and post-socialist societies (Nee 1996; Szelenyi 1978; Szelenyi and Kostello 1996), and to argue that institutional constraints on markets can actually improve an economy's overall performance (Streek 1998, 2008), to the author's knowledge no study uses such a perspective to assess income inequality. I begin the study by documenting recent changes in income inequality in advanced capitalist countries and then developing the argument that three protective institutions-the public sector economy, trade unions, and the family-play crucial roles in shaping the national distribution of income. Next, I empirically confirm the relationship between protective institutions and income inequality with data on 16 Western countries observed intermittedly from 1970 to 2010 . Then, comparing outcomes across countries during the 2000s, I show that cross-national variations in these protective institutions map onto crossnational differences in income inequality. Finally, I conclude by arguing that a Polanyian perspective offers more analytical and theoretical leverage than other sociological approaches to understanding income inequality.

\section{ChANGES IN INCOME INEQUALITY, 1970 - 2010}

To contextualize the present study, it is instructive to begin by noting that income inequality varies substantially across advanced capitalist countries, even though these 
countries are similar in many other ways. This degree of variation is shown in figure 1 , which portrays net income inequality estimates from the Luxembourg Income Study (LIS) (2014) for the 16 countries used in this study over recent decades. The LIS gathers detailed data from nationally representative household surveys, and then harmonizes these data to yield estimates that are methodologically consistent across countries and across years. The national surveys are conducted approximately every five years, starting for some countries in early 1970s and for others in the mid-1980s. The resulting estimates, expressed as Gini coefficients multiplied by 100 , account for the moderating effects of taxes and social transfers, meaning that they reflect the distribution of disposable rather than gross income.

These data illustrate that, in at least two ways, the United States and (to a lesser degree) the United Kingdom are anomalous. First, these two countries experienced significant and sustained upturns in inequality starting in the early 1980s, yet similar patterns of change are hard to detect in other countries. Rather, the estimates from the LIS suggest that most countries have experienced trendless fluctuations or modest changes in their levels of income inequality. Second, the United States and the United Kingdom have considerably higher levels of income inequality than the other countries in the sample. To illustrate this point, the highest level of income inequality within the sample is denoted by a dashed line, which runs across each national plot. The highest level of inequality-a Gini coefficient of 37.8-was recorded in the United States in 2007. Except for recent estimates from the United Kingdom (which has had Gini coefficients close to 35), the other countries in the sample do not have income inequality of this magnitude.

[Insert figure 1 about here.]

How can the cross-national and temporal patterns shown in figure 1 be explained? The present study now turns to the argument that the distribution of income in advanced capitalist countries is substantially shaped by protective institutions that shield individuals from the full force of the market. These protective institutions have long historical roots, but became firmly entrenched as universal pillars of the socio-economic order of Western capitalism during the mid-20 $0^{\text {th }}$ century. Where they have remained robust, income inequality has remained at modest levels. But where they have weakened, income inequality has risen accordingly. For the United States and the United Kingdom in particular, their unusually high levels of income inequality are linked not to their greater 
exposure to globalization or technological change, but rather to the growing weakness of their protective institutions, which in prior decades had helped to kept market-generated inequality at bay.

\section{Protective InSTITUTIONS AND INCOME INEQUALITY}

Many historically prominent social scientists have concluded that capitalist markets do many things very well, but generating social stability and economic equality is not one of them (Keynes 1936; Marx 1867/2000; Polanyi 1944). On this subject, Polanyi's (1944) renowned analysis of the rise and fall of classic liberalism in Britain has been particularly influential. He held that, until the "utopian" efforts of 19th-century Britain, no society had attempted to build an economy wholly around free markets. Instead, the historic norm was that economies used multiple distributive systems, with markets typically playing auxiliary roles to distributive systems based on reciprocity and redistribution (see also Polanyi 1968). The paradox for $19^{\text {th }}$-century Britain was that the expansion of the market produced unparalleled wealth on one hand, but a cascade of poverty and social dislocations on the other. As the market economy spread across the West, this same pattern of expanding wealth and expanding poverty was replicated in other countries. Eventually, leading capitalist powers developed systematic ways of addressing these socio-economic problems-for example, the New Deal in the United States, the Beveridgean welfare state in Britain, and corporatism in German and Italy (Mann 1996), but only after the free-market nearly destroyed Western society.

Famously, Polanyi described the classic liberal era in Britain as being shaped by a "double movement" in which attempts to expand markets by some were met with attempts to protect society from those markets by others. Although varied in form, all attempts at social protection shared the common logic of seeking to shield some segment of society from the market. For the purposes of the present study, Polanyi makes two important points about the development of protective institutions. First, Polanyi notes that some attempts at social protection were ill-conceived and counterproductive. The Speenhamland system was notable in this regard. Used in many parts of Britain during the early-19th century, this system relied on local parishes to supplement the incomes of workers whose wages fell below the poverty line. Although well intended, Speenhamland's ultimately effect was to exacerbate the very problem it sought to overcome (see also Block and Somers 2003). This occurred because many employers reduced their wages further once they 
realized that local parishes would cover the difference, with the result being a reinforcing spiral of falling wages and rising demand for social protection. Hence, a key milestone in modern capitalism, according to Polanyi, was the repeal of Speenhamland in 1834, since this parliamentary act laid the foundation for a labor market governed by supply and demand.

Second, in a significant deviation from other critics of capitalism, Polanyi argues that the mobilization for social protection was undertaken not by the working class in particular, but by broad cross-sections of society, even though the latter may have been the biggest beneficiary of this social movement. In taking this position, Polanyi significantly differentiates himself from the Marxist tradition, which long views the working class and its struggles against capitalist exploitation as the primary engine of progressive social change. Polanyi bases his argument on the notion that unfettered markets imperil not just workers and natural resources, but "the whole organization of capitalistic production itself" (19944:138). Hence, at different times and in different ways, the emergence of markets in 19th-century Britain threatened farmers, landlords, manufacturers, traders, artisan, trade unionists, unskilled laborers, and the poor. Often, cross-sections of individuals from these groups and classes pushed for specific interventions, such as the regulation of working conditions, restrictions on the use of land, or tariffs in support of domestic industry. At other times, cross-sections mobilized for the development of important non-market institutions, which could provide the general public with important services not being adequately provided by the market. This includes services related to public safety, sanitation, health care, education, transportation, culture and recreation, among many others. In sum, Polanyi maintains that an economy that allocates the factors of production purely through the market mechanism threatens the very fabric of society, and hence the mobilization against these threats are often broad based, although clearly shaped by the class interests involved.

These ideas on the interplay between markets and society have influenced sociologists interested in understanding how capitalist societies reconcile conflicting social and economic imperatives (Ringmar 2005; Breen 1997). In this regard, Ringmar's (2005) historical analysis of Western and East Asian societies holds that prosperous countries find ways to empower markets on one hand, but protect their citizens from undesirable market force on the other hand. He concludes that this form of political economy-in which the 
effects of markets are buffered by non-market institutions-is not without its problems, but works reasonably well most of the time. Like Polanyi, Ringmar believes that capitalist societies can use a variety of strategies to balance social and economic imperatives, but he highlights three protective institutions as being the most important-the state, guilds and trade unions, and the family. Each developed and evolved over considerable periods of time, but by the post-war period they had become firmly entrenched as universal features of the socio-economic order of these societies.

Similar ideas can be found elsewhere in the social sciences. For example, in economics, some scholars argue that "equalizing institutions" (Levy 1998) or "countervailing power" (Galbraith 1952) are important mechanisms for offsetting market excesses and producing stable economic growth. In international relations, scholars use the term "embedded liberalism" to describe the post-war international economic order (Ruggie 1982). This economic order was "liberal" in that it promoted free trade, but "embedded" in that it constrained international capital mobility as a means of preserving the domestic policy autonomy of individual states.

The section below further outlines the rationale for why the three protective institutions identified by Ringmar should help to mitigate income inequality. My analysis slightly reframes these protective institutions by focusing on (1) the public sector economy, (2) trade unions and industrial relations systems, and (3) the dual-income family.

\section{Public Sector Economy}

Polanyi's $(1944,1968)$ perspective on economy-society relations provides a useful starting point for thinking about how the public sector economy may produce less income inequality than the private sector economy. For Polanyi, private markets are governed by the logic of "economizing"-meaning that market participants seek to increase their material well-being by choosing courses of action that maximizes their gains and minimizes their costs. In contrast, the public sector economy follows a different logic. In the Polanyian sense, it is governed not by the economizing behaviour of myriad individuals, but rather by centralized authorities seeking to fulfil certain social and political needs. From this insight, one can reasonably argue that markets and the public sector constitute unique distributive systems within contemporary capitalism, with each likely yielding distinct patterns of income inequality. Here a crucial point is that economic activity in consumer 
markets is based on competition and the pursuit of private gain, which should create abundant opportunities for individual differentiation and hence relatively high levels of income inequality. Conversely, economic activity in the public sector is oriented toward fulfilling social needs with resources obtained through taxation. The resulting economic activity, in turn, should create fewer opportunities for individual differentiation and hence relatively lower levels of income inequality. To the degree that these contentions are correct, one would expect income inequality to be high in advanced capitalist countries with small public sectors.

There is sound empirical evidence supporting this theoretical contention. Recent quantitative studies find that, at least in democratic societies, public sector spending reduces income inequality (Boyd 1988; Kollmeyer 2012; Lee 2005). This ostensibly occurs because democratic states obtain revenue through progressive taxation, but then spend the resulting resources in ways that benefit citizens across the social hierarchy. This is thought to redistribute income from high- to low-income earners. An important caveat centers on democracy. In his analysis of 64 non-communist countries over the period of 1970-1994, Lee (2005) finds that public sector spending exacerbates income inequality in nondemocratic countries, but reduces it in democratic countries. The difference is attributed to divergent spending priorities, with nondemocratic states often using public resources to promote the narrow interests of elites and favored industries, but democratic states often using public resources to advance broad interests or to alleviate poverty and inequality.

\section{Trade Unions and Collective Bargaining Structures}

As important protective institutions, trade unions have historically offered workers the possibility that they can bend market outcomes toward their interests. The lone worker must accept prevailing market conditions, even if those conditions are heavily weighted against him or her. But large groups of workers, acting in a coordinated fashion, can exert some influence over market conditions, changing them in ways that improve their collective welfare. Hence, a prominent view in the social sciences holds that economic outcomes in advanced capitalist countries reflect not only anonymous market forces, but also the organizational power of workers (e.g. Esping-Anderson 1985; Bradley et al 2003; Korpi 1983). 
There are at least three reasons why strong trade unions should lower national income inequality. (1) By amplifying the bargaining power of workers, trade unions tend to enlarge labor's share of national income, meaning that more of the income generated from the economy ends up in the form of wages and salary rather than profits and rents (Kristal 2010; Rubin 1986; Wallace, Leicht, and Raffalovich 1999). (2) Trade unions tend to reduce the gap between high- and low-income workers (Pontusson, Rueda, and Way 2002; Rueda and Pontusson 2000). This occurs because the logic of collective action generates preferences for compact wage scales, in which some of the potential incomes of highearning members are sacrificed in exchange for higher incomes for low-earning members. (3) By affecting prevailing social norms, trade unions can influence wage inequality in nonunionized sectors of the economy. As Western and Rosenfeld (2011) argue, trade unions promote, defuse and reinforce societal views that sanction economic equality as a desired social outcome. Hence, when trade unions are powerful, norms sanctioning equality become deeply ingrained in the workplace, helping to curtail wage dispersion in unionized and non-unionized sectors of the economy alike.

Furthermore, the systems in which wages are set and economic policy formed are thought to influence the national income distribution. In corporatist systems, such as those found in Sweden and Austria, decisions about wages and related issues are made through tripartite negotiations at the national level, with the resulting decisions being uniformly implemented by local employers and trade unions. In decentralized systems, such as those found in the United States and the United Kingdom, individual workers or local trade unions negotiate directly with local employers, leaving trade unions with little direct influence over national economic policy. Importantly, by giving workers the institutional capacity to consider their common interests, corporatism is thought to generate collective preferences for equality. This idea is supported by numerous studies, each finding that corporatism generates relatively compact wage distributions (Pontusson, Rueda, and Way 2002; Rueda and Pontusson 2000; Wallerstein 1999) and reduces overall levels of income inequality (Alderson and Nielsen 2002; Bradley et al. 2003; Mahler 2004).

\section{Family Formations and Female Labor Market Participation}

The family is an important and long-standing protective institution, because it allows for the pooling of incomes among multiple income earners and the redistribution of 
income from working to non-working members of society. Family formations have varied across history, but during the mid-20 $0^{\text {th }}$ century, strong social forces led most families in the West to adopt the male-breadwinner model, in which the father participated in the labor market and the mother engaged in unpaid domestic work. For the reasons discussed below, recent movements away from this family formation are likely to have significant distributional consequences, with the specific effect depending on the particular composition of changes occurring in each country.

One prominent familial change is the growing prevalence of families headed by single mothers. This trend should heighten national income inequality for several reasons. (1) Given growth in the number of dual-income families, families headed by single mothers have one less source of income than many other families and households. (2) The persistence of a gender wage gap means that the earnings of single mothers will, on average, lag behind the earnings of comparably situated men. Finally, (3) at least in the United States, single mothers tend to be less educated than other women (McLanahan and Percheski 2008). The combined effect of these three factors- more dual-income families, lower pay for women, and low educational attainments of single mothers-means that many single-mother families will have household incomes below the national median. Hence, as their numbers grow, national income inequality should rise due to the concomitant increase in the number of lower-income families. This disequalizing effect is well documented for the United States (e.g. Treas 1987; Moller, Alderson, and Nielsen 2009; Western, Bloome and Percheski 2008), and seems to occur more generally across advanced capitalist countries (Kollmeyer 2013).

A second important familial change, occurring over recent decades, is the steady rise in female labor market participation. Although contested (see Schwartz 2010), strong evidence suggests that this trend has an equalizing effect on the national income distribution. Here the theoretical explanation is that increasing numbers of women in the paid workforce spreads income more widely across society and provides additional (and much-needed) income to many lower-income families, with the combined effect being a reduction in national income inequality. Numerous studies on the United States support this view, although the distributional effects appear to vary from decade to decade, depending on the types of women drawn into the workforce (Treas 1987; Moller, Alderson, 
and Nielsen 2009; Western, Bloome and Percheski 2008). Recent cross-national research yields similar conclusions (Kollmeyer 2013).

Finally, a related demographic factor with distributional consequences is the changing size of economically inactive populations. A basic assumption of demographic approaches to studying income inequality is that national populations can be divided into distinct groups-in this case those who are economically active and those who are economically inactive-and that each group will have an associated mean income (see Gustafsson and Johansson 1999; Western, Bloome and Percheski 2008). For the present study, it can be assumed that economically inactive groups will have lower mean incomes than economically active groups. From this assumption, it follows that if the relative size of the economically inactive populations increases, or if their relative mean income falls, then national distribution of income will be more unequal. Scholars such as Gustafsson and Johansson (1999) have generated compelling evidence of this distributional effect. For the present study, this factor should be considered largely because the countries in the sample have aging populations, which should result in more households comprised of economically inactive retirees with incomes below the national median.

\section{Cross-National Variation in Protective InSTitution STREngth}

By the post-war period, the three protective institutions described above had become important pillars of the socio-economic order of advanced capitalism, helping to secure several decades of stable economic growth and widespread prosperity. Of great importance to the present study is the fact that (1) the strength of these protective institutions vary considerably across advanced capitalist countries, and that (2) this crossnational variation has become more pronounced over recent decades. These two points can be seen in table 1, which displays averages measures of the strength of key protective institutions from the 1970 s and the 2000s for the 16 countries in the sample. For each of the four measures, there is considerable variation across the sample, and this variation appears to map onto levels of income inequality. For instance, Denmark, with some of the lowest income inequality in the sample, has some of the most favorable scores on all measures except the percentage of children living with single mothers. Conversely, the United States, with the highest income inequality in the sample, has some of the least favorable scores on all measures except female labor market participation. Furthermore, 
these differences are generally becoming more pronounced. This can been seen in the sample standard deviations, which are larger in the 2000s than the 1970s for all measures except female labor market participation.

[Insert table 1 about here.]

\section{EMPIRICAL EVIDENCE: PANEL DATA}

To test my argument that protective institutions are important determinants of income inequality, and hence can help to explain why some countries have recently experienced rising inequality while others have not, I collect data on 16 Western countries from 1970 to 2010. The 16 countries are Australia, Austria, Belgium, Canada, Denmark, Finland, France, Germany, Ireland, Italy, Netherlands, Norway, Sweden, Switzerland, the United Kingdom, and the United States. The data set is unbalanced, because income inequality estimates from the LIS, the best source for such data, are taken only two or three times per decade. Consequentially, the dataset contains a maximum of 131 observations per variable. Given that the measurement of study's variables are straightforward, and given that I wish to focus on the empirical findings rather than the data and statistical methods, I streamline this section by presenting information about the variables in table 2 , but not discussing their construction in the text as well. I also streamline the discussion of the estimating strategy used below.

[Insert table 2 about here.]

The empirical analysis begins by examining the bivariate relationships between income inequality and the three protective institutions discussed above. As shown in figure 2, these bivariate relationships are depicted by the directional pattern of the scatter plots, by the prediction lines fitted to these scatter plots, and by the associated Pearson correlation coefficients $(r)$. These bivariate analyses reveal that net income inequality has a strong and negative correlation with public sector (\%GDP) and trade union density. The strength of these associations, as depicted by the Pearson correlation coefficient, are reasonably strong and very similar to one another ( $r=-.57$ and $r=-.65$, respectively). These bivariate analyses suggest that changes in family composition affect income inequality as well. In particular, the data show that net income inequality is positively correlated with \% of Children Living with Single Mothers $(r=0.28)$, but negatively correlated 
with Female Labor Market Participation $(r=-0.28)$. Overall, these bivariate relationships suggest that all three of these protective institutions do indeed have important distributional effects.

[Insert figure 2 about here.]

The study now examines these relationships with standard panel regression techniques. Put succinctly, my estimating strategy uses country-specific error terms to account for unmeasured cross-sectional effects, a battery of year-dummy variables to account for unmeasured temporal effects, and panel-clustered robust standard errors to account for serial correlation and groupwise heteroscedasticity. These steps create a random effects (RE) model (which is estimated by generalized least squares) with panelclustered robust standard errors. This estimating strategy has been used in prominent studies of income inequality, which also use repeat observation of several Western countries (Alderson. and Nielsen 2002; Kollmeyer 2012, 2013; Brady and Leicht 2008; Gustafsson and Johansson 1999). These adaptations are necessary because ordinary least squares regression assumes that the observations comprising the sample are unrelated, but with panel data, many observations share temporal and cross-sectional linkages. My RE model accounts for these linkages, as well as serial correlation and groupwise heteroscedasticity (both of which can inflate standard errors if not properly addressed). The regression analysis proceeds first by examining the distributional effects of the three protective institutions separately, and then examining all of the protective institutions simultaneously.

Table 3 shows results from seven RE regression models, each assessing how various protective institutions affect net income inequality. Model 1 begins by introducing a simple bivariate model, in which the size of the public sector is regressed against net income inequality. Based on the discussion above, the expectation is that the size of the public sector should be inversely related income inequality, because at least in democratic countries, the public sector economy is thought to be inherently redistributive. Consistent with this expectation, the parameter estimate for public sector (\%GDP) is negative and statistically significant, suggesting that income inequality falls when the public sector economy expands. Model 2 extends this simple bivariate model by introducing a measure of the average generosity of three social welfare programs-unemployment, disability, and 
old-age insurance-which are used in all of the 16 countries in the sample. Generosity is measured as the percentage of a worker's prior income that is replaced by the social insurance program. As expected, under this multivariate model, the parameter estimates for both public sector (\%GDP) and generosity of welfare benefits are negative and statistically significant. This result suggests that, net of the equalizing effects of the public sector economy, generous social protections also exert downward pressure on income inequality.

[Insert table 3 about here.]

The next regression model assesses how trade union strength and the composition of the industrial relations system affect national income inequality. Specifically, model 3 finds a negative and statistically significant parameter estimate for trade union density, suggesting that income inequality falls as the unionized percentage of the workforce increases. Model 4 extends this finding by considering whether the characteristics of the industrial relations systems used in particular countries influence the distribution of income. This is done by adding two measures of corporatism to the existing model of trade union strength. As expected, the result show that trade union density, centralized wage bargaining, and policy bargaining all have negative parameter estimates. Unexpectedly, however, the parameter estimate for centralized wage bargaining is not statistically significant, an outcome that changes in the full model discussed below.

The next set of regression models assesses whether recent changes in familial structure are affecting the national distribution of income. The main contention is that the family often functions as a protective institution, since it can pool incomes across multiple earners and redistribute income from working to non-working members of society. In particular, this contention rests on two interrelated expectations: (1) that increases in female paid employment should reduce income inequality (since it should enhance the capacity of families to pool incomes), but (2) that increases in households headed by single mothers should heighten income inequality (since such families cannot pool incomes and face entrenched barriers in the labor market). To begin to test these expectations, model 5 isolates the distributional effects of female labor market participation. As anticipated, this parameter estimate is negative and statistically significant, suggesting that the growing numbers of women in the paid workforce have helped to moderate income equality over recent decades. Model 6 extends this finding and tests the second expectation by 
introducing the \% of children living with single mothers as well as other demographic measures. As expected, this expanded model shows that female labor market participation is negative and statistically significant, but that the \% of children living with single mothers is positive and statistically significant. Hence, the two trends have offsetting distributional effects.

Model 6 also controls for the size of a country's economically inactive population. As demonstrated by Gustafsson and Johansson (1999), economically inactive populations are likely to heighten income inequality. This occurs presumably because their average incomes are lower than those of economically active populations. But this may occur for more idiosyncratic reasons as well. Here the main factor is that the LIS weights each household's income by the square root of the number of its members, resulting in what the LIS calls "equivalent household income." Given that children increase household size without increasing household income, large populations of children should put upward pressure on the LIS's estimates of income inequality. Hence, the expectation is that an increase in the economically inactive population (whether it come from children or pensioners) should generate a disequalizing effect on the distribution of income. The results fromn model 6, however, are inconsistent with this expectation, as the parameter estimates for population under 16 and population over 65 are statistically insignificant. Importantly, this result changes in the final model.

It is also worth noting that the magnitude of the parameter estimate for female labor market participation is larger in the multivariate model than the bivariate model. This outcome likely reflects the presence of a confounding association between paid female employment and single motherhood, as each effects net income inequality. Most likely, some women are entering the paid workforce precisely because they are single parents and cannot rely on the incomes of their spouses or partners for financial support. Hence, once the model accounts for the disequalizing effect of single motherhood, the remaining equalizing effect of female employment on income inequality becomes larger.

Lastly, model 7 simultaneously estimates the parameters for all variables appearing in the previous six models. As one would expected, some of the parameter estimates are smaller under this more comprehensive model since confounding factors are held constant. This is the case, for example, for trade union density. Its parameter estimate fell from $\mathrm{b}=$ 0.089 in model 4 to $b=-0.049$ in model 7 . Notably, the parameter estimates for the 
economically inactive populations change as well. While estimated to be statistically insignificant in model 6, the parameters for population under 16 and population over 65 are now positive and statistically significant, suggesting that economically inactive populations do indeed heighten income inequality. This changing result is likely due to confounding effects among population under 16 and population over 65 and other independent variables in the model. For example, the size of public sector economy and the generosity of social insurance is associated with services and transfers specifically targeting young and old populations. Also trade unions strength may affect the ability of workers to receive a "family wage" to cover the costs of children, or to bolster pensions for their retirement. Once the comprehensive model accounts for these factors, the remaining disequalizing effects associated with economically inactive populations manifest more clearly.

\section{EMPIRICAl EVIDENCE: Cross-SeCtional DATA}

The empirical analysis ends by examining my hypothesis from a cross-sectional perspective. In essence, this perspective asks whether net income inequality is relatively low in countries where protective institutions are strong, but relatively high in countries where protective institutions are weak. Table 4 addresses this question by comparing levels of net income inequality to the strength of protective institutions for each of the 16 countries in the sample. The measures are based on average scores from observations taking in the 2000s. This is done to create a cross-section free from distortions arising from short-term fluctuations, but one that still reasonably approximates the current state of affairs in these countries. To more clearly depict the relationship under consideration, table 4 arrays the 16 countries (from highest to lowest) based on the Gini coefficient of net income inequality.

[Insert table 4 about here.]

Consistent with the regression results discussed above, table 4 reveals strong links between the distribution of net income and the strength of three protective institutions. For example, the United States not only has the highest level of income inequality in the sample, but also very weak protective institutions relative to the sample. In fact, out of 16 countries, the United States has the second smallest public sector, the second lowest trade union density, and second highest percentage of children living with single mothers. These 
disequalizing effects, however, are slightly mitigated by the US's level of female labor market participation, which is close to the sample mean. Overall, this cross-sectional view strongly suggests that the United States has high income inequality largely because it has weak protective institutions.

The congruence between income inequality and the strength of protective institutions holds not just for the United States, but for countries at the other end of the income-inequality spectrum. As my general argument anticipates, the Nordic countries not only have low levels of income inequality, but also robust protective institutions. In particular, they have large public sector economies, highly unionized labor forces, and high levels of female labor market participation. These equalizing effects, however, are slightly undermined by the large numbers of children living with single mothers-an outcome that prevents net income inequality in these countries from being even lower. Nonetheless, the strong congruence between the strength of these protective institutions and prevailing levels of net income inequality hold across the sample.

\section{CONCLUSION AND DISCUSSION}

Despite enormous influence on the social sciences, Polanyi's ideas about societymarket relations have received scant attention from scholars interested in income inequality. The rare exception has been a handful of studies on social stratification in socialist and post-socialist societies (Nee 1996; Szelenyi 1978; Szelenyi and Kostello 1996). This oversight is unfortunate since Polanyi's account of how capitalist societies protect themselves from socially destructive market forces is highly relevant to the study of income inequality. Hoping to pod the literature in this direction, the present study is the first to assess income inequality from a Polanyian perspective. Extending Ringmar's (2005) qualitative analysis of protective institutions, my main contention is that cross-national and temporal variations in three protective institutions-the public sector economy, trade unions, and the family-largely explain observed variations in national income inequality across affluent Western countries. Using a range of statistical methods, I empirically support this contention with data on 16 Western countries observed intermittedly between 1970 and 2010.

This study contributes to the study of income inequality by conceptualizing the

public sector economy, trade unions, and the family as protective institutions with 
significant distributional effects. In Polanyi's account of capitalist society, the development of non-market institutions within the economy is not an aberration in an otherwise selfregulating system of market exchange. Instead, it is part and parcel of capitalist society, largely because these non-market institutions play indispensible roles in reconciling tensions between market and social imperatives. Without social protection, market forces are likely to undermine the workings of the economy and society alike. Importantly, this led Polanyi to contend that protective institutions are not necessarily instruments of working class power, but rather mechanisms to stabilize society and improve the wellbeing of people from diverse class backgrounds. Drawing on this theoretical perspective, my study empirically demonstrates that protective institutions linked to the state, civil society, and the family can generate a relatively egalitarian distribution of income within the context of capitalism. Although no country in the study is uniformly strong across all protective institutions, the data assembled here clearly shows a pattern between national income inequality and the robustness of these protective institutions.

Potentially, this Polanyian perspective can offer more analytical and theoretical leverage than other perspectives on income inequality. Many sociological studies of income inequality draw upon "power resource theory" to explicate the causal mechanisms shaping the national income distribution. As applied by Bradley et al (2003), this perspective extends Marxian notions of class conflict to posit that the organizational strength of the working class and the power of left-labor parties are crucial determinants of income inequality. As applied by Brady and Leicht (2008), this perspective also considers how the power of capitalist elites-wielded through right political parties-can shape income inequality. Hence, in total, "power resource theory" views the balance of class powerwhich then shapes trade unions, political parties, and welfare states-as the primary driver of distributional outcomes. Implicitly, such a perspective highlights the working class as the social actor whose agency pushes back against the extremes of capitalism and reshapes the national income distribution in a more egalitarian fashion. This infers that income inequality should be relatively low when the working class is organized and motivated, but relatively high when the working class is disorganized and indifferent.

However, viewing the working class' organizational and political power as the linchpin to distributional dynamics may be unwarranted. As some scholars note, the contemporary working class is less politically active and less uniformly left in its political 
orientation than the working class of previous generations (i.e. Hechter 2004). Partially for this reason, Brady and Leicht call attention to the political right's capacity to mould the distribution of income in their favour. Here one of their main points is that, unlike large segments of the working class in some countries today, capitalist elites and their political allies have not demobilized around class issues, and hence their political power should still be positively linked to income inequality.

By contrast, the Polanyian perspective used in this study takes another view of class. Although Polanyi realized the importance of class in shaping society, he contended that "class interests offer only a limited explanation of long-run movements in society" (1944: 159). He saw protective institutions as being indicative of this general trend. In practical terms, this means that diverse social groups-often more than particular classesare the champions of protective institutions. For example, in Britain today, the public sector receives political support not only from the working class, but also from sizeable segments of the middle class. The latter's support is linked to the fact the British public sector employs the vast majority of the country's doctors and university lecturers as well as large numbers of other middle-class professionals. Furthermore, many of these public sector professionals are trade union members. Consequently, the public sector and trade unions often receive support from cross-sections of the middle and working classes, even though members of these classes might differ on a range of other contentious issues. Similar points could be made about the family as a protective institution transversing class politics. For example, one could easily imagine the wealthy pursuing policies that limit the prevalence of single parenthood (thereby reducing inequality), but pursue policies that shrink the public sector economy (thereby increasing inequality). Under such a scenario, the link between class and protective institutions is not always straightforward.

Overall, the Polanyian perspective generally contends that protective institutions moderate the distribution of income (which has pronounced class implications), but that the political support for these institutions can contravene traditional notions of class struggle. Such an account of class-that it matters but is not always deceive-seems consistent with the general thrust of politics in many countries today. In sum, the Polanyian perspective places the sociological study of income inequality, as it manifests in contemporary capitalist societies, on sound theoretical foundation. It does this by allowing for the possibility that diverse social actors, not just the working class, provide crucial 
support for protective institutions. This happens because a broad swath of society's members receive much-welcomed material support from protective institutions.

\section{REFERENCES}

Acemoglu, Daron. 1998. "Why do New Technologies Complement Skills? Directed Technical Change and Wage Inequality." Quarterly Journal of Economics 113(4): 1055-1089.

Alderson, Arthur and François Nielsen. 2002. "Globalization and the Great U-Turn: Income Inequality Trends in 16 OECD Countries." American Journal of Sociology 107(5):1244-1299.

Autor, David H., Lawrence F Katz, and Melissa Kearney. 2008. "Trends in U.S. Wage Inequality: Revising the Revisionists." Review of Economics and Statistics 90(2): 300-323.

Block, Fred and Margaret Somers. 2003. "In the Shadow of Speenhamland: Social Policy and the Old Poor Law." Politics \& Society 31(2): 283-323.

Boyd, Robert L. 1988. "Government Involvement in the Economy and the Distribution of Income: A Cross-National Study." Population Research and Policy Review 7(3):223-238.

Bradley, David, Evelyne Huber, Stephanie Moller, François Nielsen, John D. Stephens. 2003. "Distribution and Redistribution in Postindustrial Democracies." World Politics 55(2):193228.

Brady, David and Kevin T. Leicht. 2008. "Party to Inequality: Right Party Power and Income Inequality in Affluent Western Democracies." Research in Social Stratification and Mobility 26: 77-106.

Breen, Richard. 1997. “ Risk, Recommodification and Stratification.” Sociology 31(3): 473489.

Esping-Andersen, Gøsta. 1985. "Power and Distributional Regimes." Politics \& Society 14: 223-256.

------. 2007. "Sociological Explanations of Changing Income Distributions." American Behavioral Scientist 50(5):639-658. 
Galbraith, John Kenneth. 1952. American Capitalism: The Concept of Countervailing Power. Boston: Houghton Mifflin.

Gustafsson, Björn and Mats Johansson. 1999. "In Search of Smoking Guns: What Makes Income Inequality Vary over Time in Different Countries?" American Sociological Review 64(4):585-605.

Hechter, Michael. 2004. "From Class to Culture.” American Journal of Sociology 110(2): 400445.

Jackman, Robert W. 1980. "Keynesian Government Intervention and Income Inequality." American Sociological Review 45(1)131-137.

Keynes, John Maynard. 1936. The General Theory of Employment, Interest and Money. Cambridge: Harcourt, Brace and Company.

Kollmeyer, Christopher. 2012. “Consumer Markets and National Income Inequality: A Study of 18 Advanced Capitalist Countries." International Journal of Comparative Sociology 53(56):400-418.

Kollmeyer, Christopher. 2013. "Family Structure, Female Employment, and National Income Inequality: A Cross-National Study of 16 Western Countries." European Sociological Review 29(4):816-827.

Korpi, Walter. 1983. The Democratic Class Struggle. Boston: Routledge and Kegan.

Kristal, Tali. 2010. “Good Times, Bad Times : Postwar Labor's Share of National Income in Capitalist Democracies." American Sociological Review 75(5) 729-763.

Lee, Cheol-Sung. 2005. "Income Inequality, Democracy, and Public Sector Size." American Sociological Review 70(1): 158-181.

Levy, Frank. 1998. The New Dollars and Dreams: American Incomes and Economic Change. New York: Russell Sage Foundation.

Levy, Frank, and Richard J. Murnane. 2003. "The Skill Content of Recent Technological Change: An Empirical Exploration." Quarterly Journal of Economics 118(4): 1279-1333. 
Luxembourg Income Study. 2014. "Inequality and Poverty Key Figures." Accessed at http://www.lisproject.org/key-figures/key-figures.htm (23 June 2014).

Mahler, Vincent A. 2004. "Economic Globalization, Domestic Politics, and Income Inequality in the Developed Countries." Comparative Political Studies 37(9):1025-1053.

Mann, Michael. 1996. “"Ruling Class Strategies and Citizenship.” In Citizenship Today: the Contemporary Relevance of T.H. Marshall, edited by Martin Bulmer and Anthony M. Rees. London: UCL Press.

Marx, Karl. 1867/2000. Das Kapital. Washington, D.C.: Regnery Gateway

McLanahan, Sara and Christine Percheski. 2008. "Family Structure and the Reproduction of Inequalities." Annual Review of Sociology 34:257-276.

Moller, Stephanie, Arthur S. Alderson, and François Nielsen. 2009. "Changing Patterns of Income Inequality in U.S. Counties, 1970-2000." American Journal of Sociology 114(4):1037-1101.

Nee, Victor. 1996. "The Emergence of a Market Society: Changing Mechanisms of Stratification in China." American Journal of Sociology 101( 4): 908-949.

OECD. 2014a. "Labour Force Statistics: Summary Tables.” OECD Employment and Labour Market Statistics. Accessed at http://stats.oecd.org/Index.aspx?DataSetCode=ALFS_SUMTAB (23 June 2014).

OECD. 2014b. “Gross Domestic Product and Main Aggregates.” OECD National Accounts Statistics. Accessed at http://www.oecdilibrary.org/economics/data/oecd-national-accounts-statistics_na-data-en (23 June 2014).

Polanyi, Karl. 1944. The Great Transformation: The Political and Economic Origins of Our Time. New York: Farrar \& Rinehart.

1968. Primitive, Archaic and Modern Economies: Essays of Karl Polanyi. Edited by George Dalton. New York: Beacon Press. 
Pontusson, Jonas, David Rueda, and Christopher R. Way. 2002. Comparative Political Economy of Wage Distribution: The Role of Partisanship and Labour Market Institutions." British Journal of Political Science 32: 281-308.

Ringmar, Erik. 2005. Surviving Capitalism: How We Learned to Live with the Market and Remained Almost Human. London: Anthem Press.

Rubin, Beth A. 1986. "Trade Union Organization, Labor Militancy, and Labor's Share of National Income in the United States, 1949-1978." Research in Social Stratification and Mobility 5:223-42.

Rueda, David and Jonas Pontusson. 2000. "Wage Inequality and Varieties of Capitalism." World Politics 52(3):350-383.

Ruggie, John Gerard. 1982. "International Regimes, Transactions, and Change: Embedded Liberalism in the Postwar Economic Order." International Organization 36(2): 379-415.

Schwartz, Christine R. 2010. "Earnings Inequality and the Changing Association between Spouses' Earnings." American Journal of Sociology 115(5):1524-1557.

Scruggs, Lyle, Detlef Jahn and Kati Kuitto. 2014. "Comparative Welfare Entitlements Dataset 2. Version 2014-03." University of Connecticut \& University of Greifswald. Accessed at http://cwed2.org/ (8 July 2014).

Stack, Steven. 1978. "The Effect of Direct Government Involvement in the Economy on the Degree of Income Inequality: A Cross-National Study." American Sociological Review 43(6):880-88.

Streeck, Wolfgang. 1998. "Beneficial Constraints: On the Economic Limits of Rational Voluntarism." In Contemporary Capitalism: The Embeddedness of Institutions, edited by J.R. Hollingsworth and Robert Boyer. Cambridge. Cambridge University Press.

2008. Re-forming Capitalism: Institutional Change in the German Political Economy. Oxford: Oxford University Press. 
Szelenyi, Ivan. 1978. "Social Inequalities in State Socialist Redistributive Economies." International Journal of Comparative Sociology 19: 63-87.

Szelenyi, Ivan and Eric Kostello. 1996. "The Market Transition Debate: Toward a Synthesis?" American Journal of Sociology 101( 4): 1082-1096.

Treas, Judith. 1987. "The Effect of Women's Labor Force Participation on the Distribution of Income in the United States." Annual Review of Sociology 13:259-288

Visser, Jelle. 2014. Database on Institutional Characteristics of Trade Unions, Wage Setting, tate Intervention and Social Pacts in 34 Countries between 1960 and 2012, Version 4. Amsterdam: Amsterdam Institute for Advanced Labour Studies.

Wallerstein, Michael. 1999. "Wage-Setting Institutions and Pay Inequality in Advanced Industrial Societies." American Journal of Political Science 43(3): 649-680.

Wallace, Michael, Kevin T. Leicht, and Lawrence E. Raffalovich. 1999. "Unions, Strikes, and Labor's Share of Income: A Quarterly Analysis of the United States, 1949-1992." Social Science Research 28(3):265-288.

Western Bruce, Deirdre Bloome and Christine Percheski. 2008. "Inequality among American Families with Children, 1975 to 2005." American Sociological Review 73(6):903-920.

Western, Bruce and Jake Rosenfeld. 2011. "Unions, Norms, and the Rise in U.S. Wage Inequality." American Sociological Review 76(4): 513-537. 
Table 1: Variation in the Strength of Protective Institutions: Average Scores from the 1970s and the 2000s for 16 Advanced Capitalist Countries.

\begin{tabular}{|c|c|c|c|c|c|c|c|c|c|c|c|c|}
\hline & \multicolumn{3}{|c|}{$\begin{array}{c}\text { Public Sector } \\
(\% G D P)\end{array}$} & \multicolumn{3}{|c|}{$\begin{array}{c}\text { Trade Union } \\
\text { Density }\end{array}$} & \multicolumn{3}{|c|}{$\begin{array}{l}\% \text { Women in } \\
\text { Labor Market }\end{array}$} & \multicolumn{3}{|c|}{$\begin{array}{c}\text { \% Kids w/ } \\
\text { Single Mothers }\end{array}$} \\
\hline & $1970 \mathrm{~s}$ & $2000 s$ & $\Delta$ & 1970s & $2000 \mathrm{~s}$ & $\Delta$ & $1970 \mathrm{~s}$ & $2000 \mathrm{~s}$ & $\Delta$ & 1980s* & $2000 s$ & $\Delta$ \\
\hline Australia & 16.1 & 17.5 & 1.4 & 48.1 & 21.0 & -27.2 & 49.0 & 68.4 & 19.4 & 9.6 & 16.8 & 7.2 \\
\hline Austria & 16.5 & 18.7 & 2.2 & 59.6 & 32.4 & -27.2 & 48.4 & 66.0 & 17.6 & 13.0 & 12.1 & -0.9 \\
\hline Belgium & 20.0 & 22.7 & 2.8 & 49.6 & 51.7 & 2.1 & 42.8 & 58.8 & 16.1 & 4.1 & 10.3 & 6.2 \\
\hline Canada & 21.1 & 19.7 & -1.4 & 33.4 & 30.0 & -3.4 & 48.7 & 72.7 & 24.0 & 9.3 & 14.0 & 4.7 \\
\hline France & 19.1 & 23.6 & 4.6 & 21.3 & 7.8 & -13.5 & 50.7 & 66.1 & 15.4 & 6.6 & 9.1 & 2.5 \\
\hline Germany & 19.4 & 18.9 & -0.4 & 33.8 & 21.4 & -12.4 & 50.4 & 67.3 & 17.0 & 6.6 & 15.2 & 8.6 \\
\hline Ireland & 19.1 & 17.0 & -2.1 & 56.3 & 34.5 & -21.8 & 34.3 & 60.6 & 26.3 & 5.3 & 18.2 & 12.9 \\
\hline Italy & 16.4 & 19.8 & 3.4 & 45.6 & 34.0 & -11.6 & 35.2 & 50.1 & 14.8 & 4.2 & 6.7 & 2.5 \\
\hline Netherlands & 22.0 & 24.9 & 2.8 & 36.9 & 20.9 & -16.0 & 32.1 & 69.7 & 37.6 & 7.3 & 10.5 & 3.2 \\
\hline United Kingdom & 20.1 & 21.0 & 0.9 & 46.7 & 28.1 & -18.6 & 54.1 & 69.0 & 14.9 & 9.4 & 21.7 & 12.3 \\
\hline United States & 17.3 & 16.0 & -1.2 & 24.0 & 12.1 & -11.9 & 53.0 & 69.7 & 16.7 & 17.8 & 20.6 & 2.8 \\
\hline Sample Mean & 18.7 & 20.5 & 1.7 & 46.5 & 36.3 & -10.3 & 51.4 & 68.6 & 17.3 & 8.8 & 14.1 & 5.3 \\
\hline Sample St. Dev. & 3.78 & 4.04 & 0.26 & 15.37 & 20.98 & 5.61 & 10.56 & 7.36 & -3.20 & 3.74 & 4.61 & 0.87 \\
\hline
\end{tabular}

Note: $\Delta$ equals the percentage-point change between the 1970 s average and the 2000s average. ${ }^{*}$ Due to data limitations, this column reports averages from the 1970s and 1980s combined. See table 2 for descriptions and sources of data. 
Table 2: Variable Descriptions and Data Sources

\begin{tabular}{|c|c|}
\hline Variable & Description and Source \\
\hline Net income inequality & $\begin{array}{l}\text { Gini coefficient of net income inequality (x 100). Data from } \\
\text { Luxembourg Income Study (2014.) }\end{array}$ \\
\hline Public sector (\%GDP) & $\begin{array}{l}\text { Annual value of government expenditures on goods and services } \\
\text { as percentage of GDP. Data from OECD (2014a). }\end{array}$ \\
\hline $\begin{array}{l}\text { Generosity of welfare } \\
\text { benefits }\end{array}$ & $\begin{array}{l}\text { Average replacement wage for unemployment, disability, and old- } \\
\text { age social insurance programs. Data from Scruggs et al (2014). }\end{array}$ \\
\hline Trade union density & Percentage of workforce in trade unions. Data from Visser (2014). \\
\hline $\begin{array}{l}\text { Centralized wage } \\
\text { bargaining }\end{array}$ & $\begin{array}{l}\text { Measure of centralization and coordination in wage bargaining, } \\
\text { ranging from " } 5 \text { " (economy-wide negotiations) to " } 1 \text { " (firm-level } \\
\text { negotiations). Data from Visser (2014). }\end{array}$ \\
\hline $\begin{array}{l}\text { Centralized policy } \\
\text { bargaining }\end{array}$ & $\begin{array}{l}\text { Measure of official trade union participation in development of } \\
\text { social and economic policy, with " } 3 \text { " equalling full participation, } \\
\text { "2" equalling partial participation, and " } 1 \text { " equalling no } \\
\text { participation. Data from Visser (2014). }\end{array}$ \\
\hline $\begin{array}{l}\text { Female labor market } \\
\text { participation }\end{array}$ & $\begin{array}{l}\text { Percentage of women aged 15-64 in paid workforce. Data from } \\
\text { OECD }(2014 b) .\end{array}$ \\
\hline $\begin{array}{l}\% \text { of children with } \\
\text { single mothers }\end{array}$ & $\begin{array}{l}\text { Percentage of children in households headed by single mothers. } \\
\text { Data from Luxembourg Income Study (2014). }\end{array}$ \\
\hline $\begin{array}{l}\text { Population }<15 \\
\text { years old }\end{array}$ & $\begin{array}{l}\text { Percentage of population aged } 15 \text { years or younger. Data from } \\
\text { OECD (2014b). }\end{array}$ \\
\hline $\begin{array}{l}\text { Population }<65 \\
\text { years old }\end{array}$ & $\begin{array}{l}\text { Percentage of population aged } 65 \text { years or older. Data from OECD } \\
(2014 \mathrm{~b}) \text {. }\end{array}$ \\
\hline
\end{tabular}


Table 3. RE Regression Estimates of Select Variables on Net Income Inequality (Gini Coefficient x 100): 16 Countries 1970 to 2010

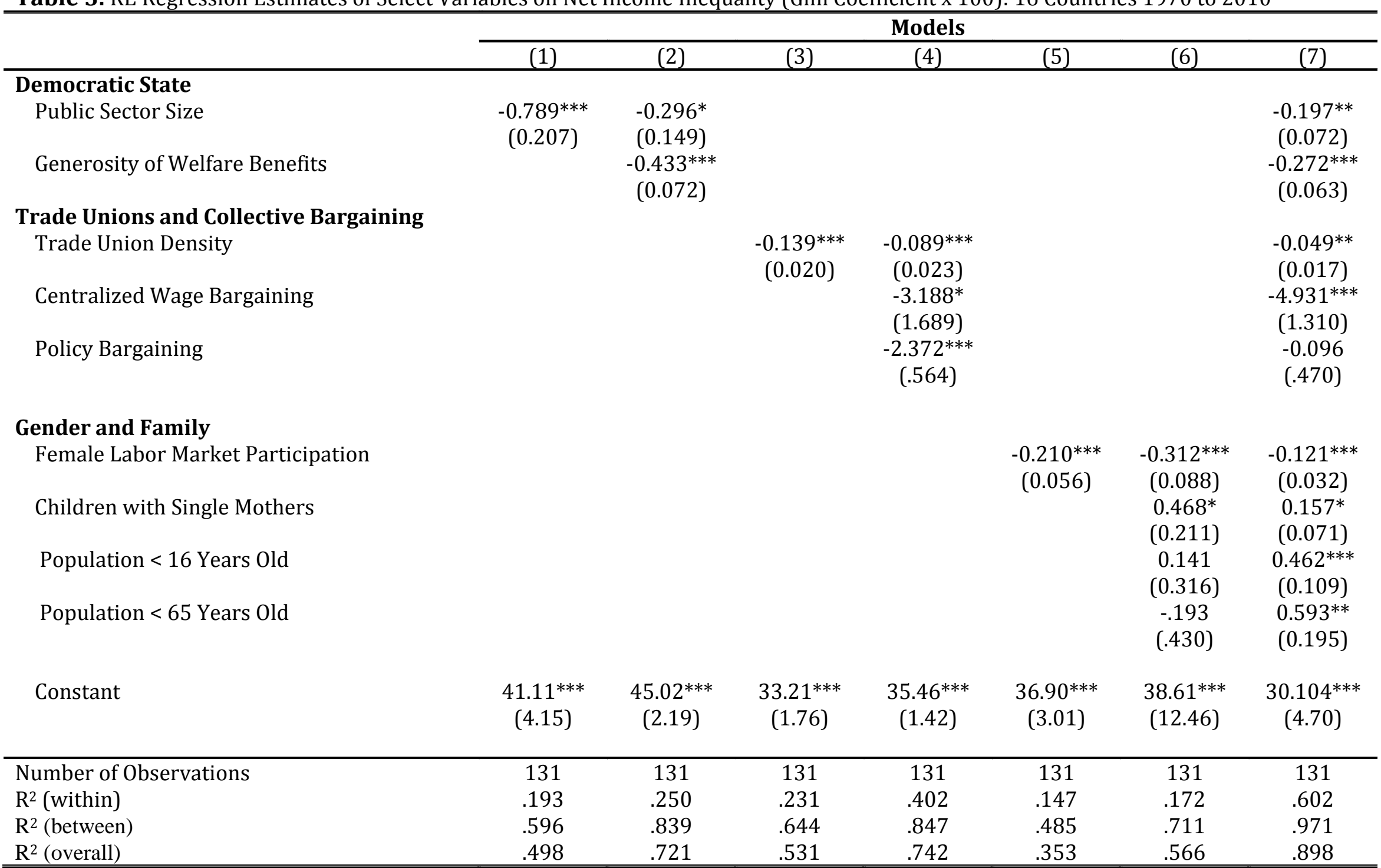

Note: Numbers in parentheses are standard errors. ${ }^{*}=\mathrm{p}<.05$; $^{* *}=\mathrm{p}<.01 ;{ }^{* * *}=\mathrm{p}<.001$. Each model includes unreported year-dummy variables. 
Table 4 . Measures of Net Income Inequality and Protective Institutions for 16 Advanced Capitalist Countries: Average Values from the 2000s

\begin{tabular}{l|ccccc}
\hline Country & $\begin{array}{c}\text { Gini } \\
\text { Coefficient } \\
(\mathrm{x} 100)\end{array}$ & $\begin{array}{c}\text { Public } \\
\text { Sector }\end{array}$ & $\begin{array}{c}\text { Trade } \\
\text { Union } \\
\text { Density }\end{array}$ & $\begin{array}{c}\text { Female } \\
\text { Employ- } \\
\text { ment }\end{array}$ & $\begin{array}{c}\text { \% Kids } \\
\text { Single } \\
\text { Mothers }\end{array}$ \\
\hline United States & 37.28 & 16.02 & 12.07 & 69.72 & 20.57 \\
United Kingdom & 35.27 & 20.97 & 28.12 & 69.04 & 21.70 \\
Italy & 33.05 & 19.76 & 34.05 & 50.06 & 6.70 \\
Canada & 31.62 & 19.70 & 29.99 & 72.72 & 13.96 \\
Australia & 31.45 & 17.49 & 20.97 & 68.42 & 16.82 \\
Ireland & 30.40 & 17.04 & 34.51 & 60.62 & 18.15 \\
Belgium & 27.90 & 22.74 & 51.72 & 58.84 & 10.34 \\
France & 27.90 & 23.36 & 7.79 & 66.12 & 9.10 \\
Germany & 27.95 & 18.93 & 21.45 & 67.33 & 15.18 \\
Switzerland & 27.40 & 11.30 & 19.51 & 78.58 & 7.25 \\
Austria & 26.30 & 18.70 & 32.41 & 66.01 & 12.08 \\
Netherlands & 26.30 & 24.88 & 21.78 & 68.58 & 9.32 \\
Norway & 24.45 & 20.65 & 54.30 & 75.82 & 13.83 \\
Finland & 25.20 & 22.34 & 72.76 & 72.74 & 12.65 \\
Sweden & 24.45 & 26.44 & 75.63 & 76.19 & 17.94 \\
Denmark & 23.48 & 26.66 & 70.94 & 76.06 & 15.61 \\
\hline & & & & & \\
Average & 29.04 & 20.45 & 36.26 & 68.64 & 14.07 \\
\hline Note: Arrayed & & & & & \\
\hline
\end{tabular}

Note: Arrayed high to low based on Gini coefficient of net income inequality (x100). 
FIGURE 1. Gini Coefficient of Net Income Inequality for 16 Western Countries, 1970 to 2010

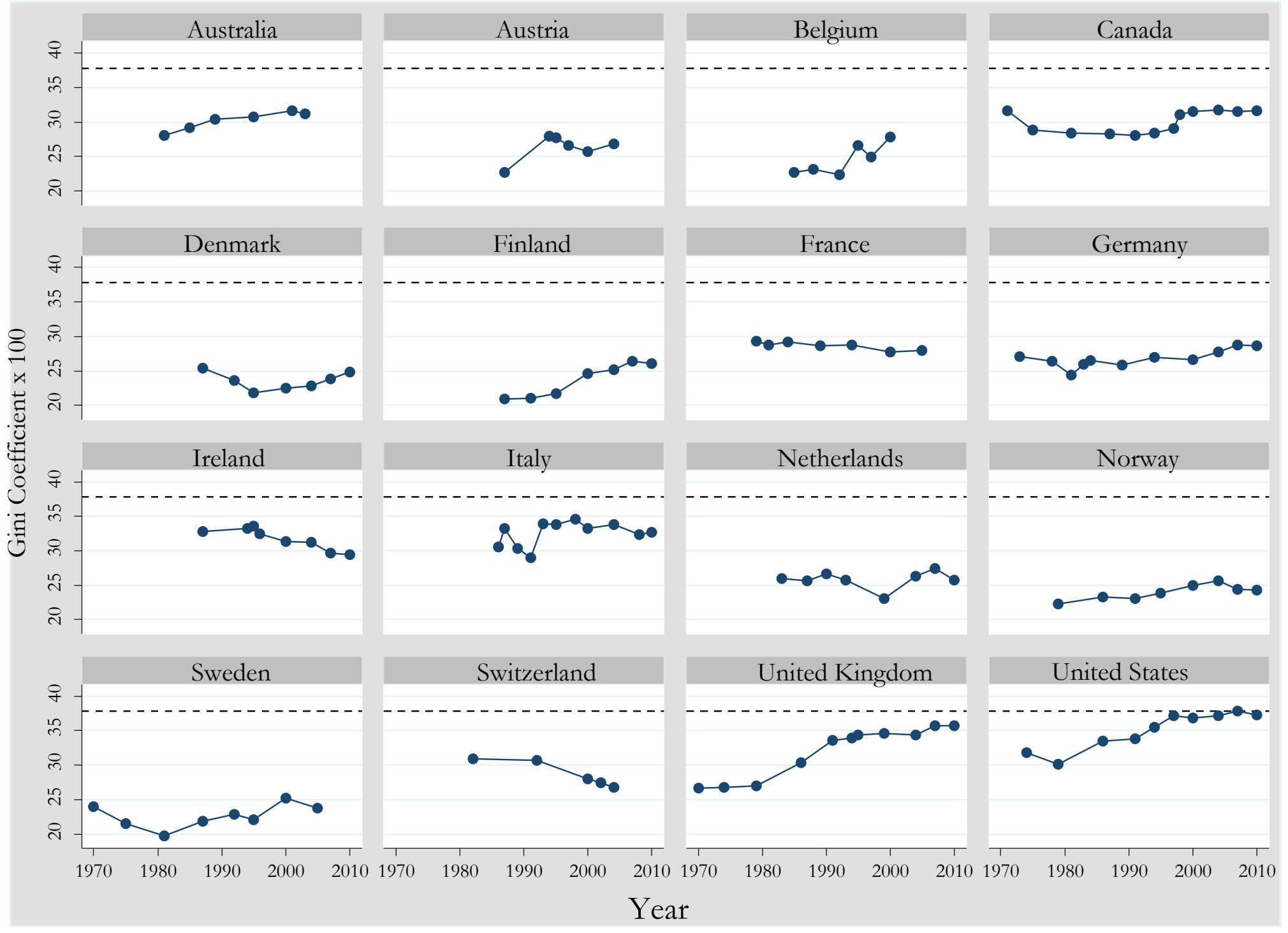


Figure 2: Scatter Plots and Correlation Coefficients for Key Variables and Income Inequality: 16 Advanced Capitalist Countries, 1970 to 2010.
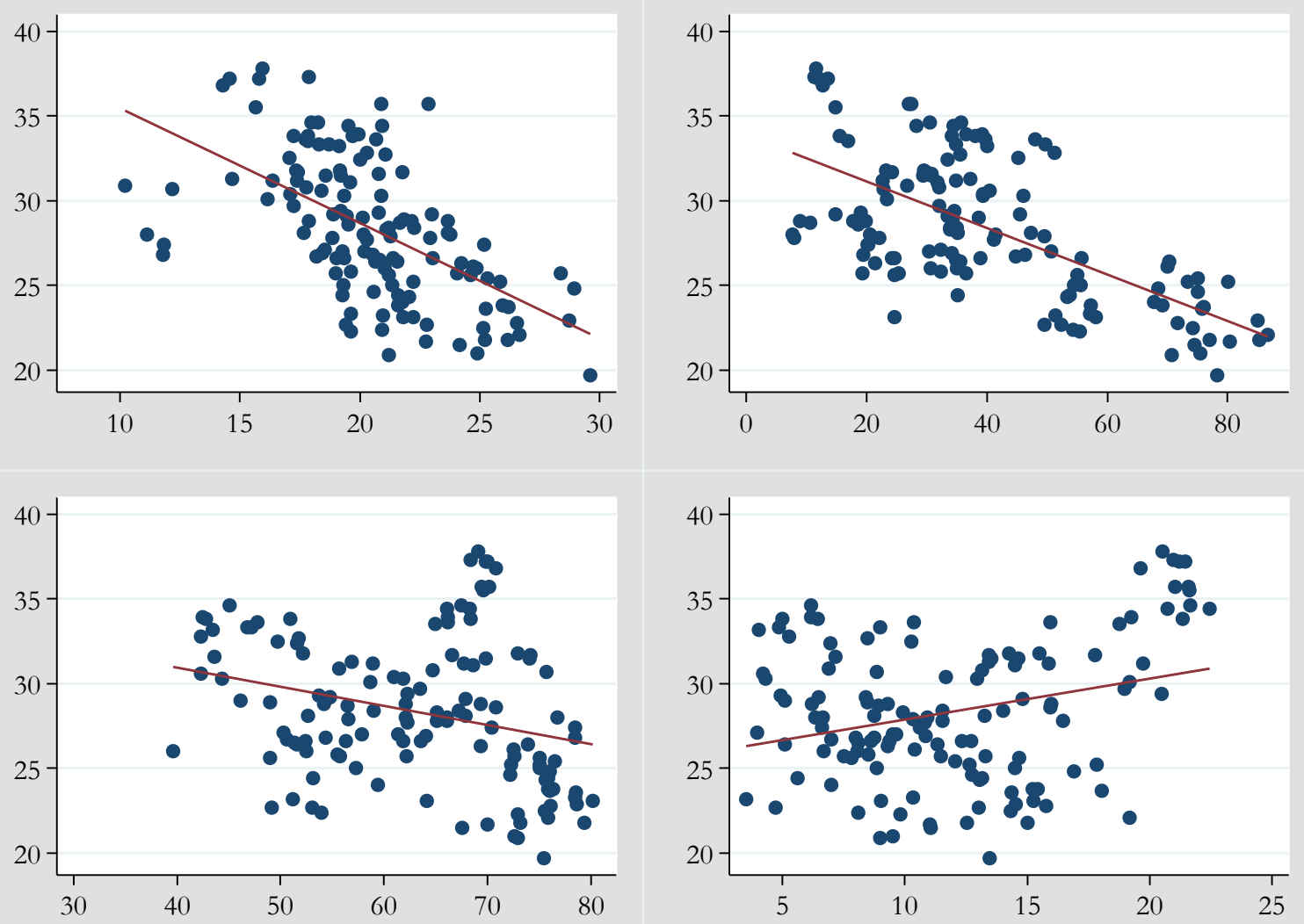

Note: Y-axes equal the Gini coefficient of net income inequality x 100. 